\title{
REFERENCES
}

1. Adamova I., Bahriy K. Testuvannia yak forma kontroliu ta diahnostyky znan studentiv [Testing as a form of control and diagnosis of students' knowledge]. Vytoky pedahohichnoi maysternosti. 2012. Vol. 9. P. 3-5 (In Ukranian).

2. Bozhkova V. V., Saher L. Yu. Testuvannia yak forma kontrolyu znan: perevahy ta nedoliky [Testing as a form of knowledge control: advantages and disadvantages]. Suchasni problemy vyshchoi osvity Ukrayiny $v$ konteksti intehratsii do yevropeyskoho osvitnoho prostoru: materialy naukovo-metodychnoi konferentsii, m. Sumy, 6-7 zhovtnya 2010 r. / za red. O. V. Prokopenko. Sumy: SumSU Publ., 2010. P. 113-115. (In Ukranian).

3. Zahrebelnyi S. L., Brus M. V. Adaptyvne testuvannia yak odyn iz sposobiv perevirky znan studentiv u tekhnichnomu vuzi [Adaptive testing as one of the ways to test students' knowledge in a technical university]. Nauchnyi vestnik DGMA. 2017. № 1 (22E). P. 155-162 (In Ukranian).

4. Sirenko S. N. Testirovanie $\mathrm{v}$ sisteme metodov kontrolya i oczenki znanij $\mathrm{v}$ sovremennom vuze [Testing in the system of methods of control and assessment of knowledge in a modern university]. Innovaczionnie obrazovatelnie tekhnologii. 2010. № 2. P. 44-51. Available at: https://elib.bsu.by/handle/123456789/4980 (In Russian) (accessed 20.01.2021).

5. Smalko O. A. Perevahy vykorystannia kompiuternykh tekhnolohii testuvannia znan u vyshchii shkoli [Benefits of using computer technology to test knowledge in universities]. Naukovi pratsi KamianetsPodilskoho natsionalnoho universytetu imeni Ivana Ohiienka: zbirnyk za pidsumkamy zvitnoi naukovoi konferentsii vykladachiv, doktorantiv i aspirantiv:: u 3-kh tomakh. Kamenets-Podolsky: KamenetsPodolsky National University named after Ivan Ogienko Publ., 2018. Vol. 17. T. 2. P. 75-76 (In Ukranian).

6. Fetisov V. S. Kompiuterni tekhnolohii v testuvanni: navch.-metod. posibnyk [Computer technology in testing]. Nizhyn: Publ. P.E. Lysenko M. M., 2011. 140 p.

7. Berwick Carly. What Does the Research Say About Testing? Edutopia / George Lucas educational fundation. October 25, 2019. Available at: https://www.edutopia.org/article/what-does-research-sayabout-testing (accessed 17.01.2021).

8. Gandal Matthew, McGiffert Laura. The Power of Testing. Educational Leadership, Feb 2003, vol. 60, № 5, p. 39-42.

9. McDermott K. B., Agarwal P. K., D’Antonio L., Roediger H. L. III \& McDaniel M. A. Both multiplechoice and short-answer quizzes enhance later exam performance in middle and high school classes. Journal of Experimental Psychology: Applied, 2014, $20(1), \quad$ p. 3-21. Available at: https://doi.org/10.1037/xap0000004 (accessed 18.01.2021).

10. Sackett P. R., Schmitt N., Ellingson J. E. \& Kabin M. B. High-stakes testing in employment, credentialing, and higher education: Prospects in a post-affirmative-action world / Sackett P. R., Schmitt N., Ellingson J. E. \& Kabin M. B. American Psychologist, 2001, 56 (4), p. 302-318. Available at: https://doi.org/10.1037/0003-066X.56.4.302 (accessed 18.01.2021).

УДК 378.018.4:364-43]:811.111

DOI 10.25128/2415-3605.21.1.7

\author{
ANASTASIIA MALOTA \\ https://orcid.org/0000-0002-1286-0118 \\ anastasiiamitiuk@gmail.com \\ postgraduate student \\ Ternopil Volodymyr Hnatiuk National Pedagogical University \\ 2 Maxym Kryvonis Str., Ternopil
}

\section{BLENDED LEARNING IN DEVELOPING PROFESSIONAL ENGLISH COMMUNICATION SKILLS OF PROSPECTIVE SOCIAL WORKERS}

The article provides the rationale for the development of professional English communication skills of prospective social workers through blended learning, analyzes and grounds the peculiarities of blended learning aimed at developing communication skills. On the basis of the survey conducted among lecturers and social workers common intercultural situations have been determined. It is concluded that effective intercultural communication requires knowledge, lexical, phonetic and grammar skills, skills of spoken production and spoken interaction, linguo-sociocultural skills. The requirements to the level of prospective social workers' English communication skills have been specified. It is concluded that blended learning should be a mixture of 


\title{
СУЧАСНІ ІНФОРМАЦІЙНО-КОМУНІКАЦІЙНІ ТЕХНОЛОГІЇ В ОСВІТІ
}

both concept based learning and collaboration-oriented learning with the face-to-face mode as the lead one; must be based on learner-centered and professional approaches, correspond to the determined principles (combination of face-to-face (approximately 65-70\%) and online (about 30-35\%) learning; students' collaboration both online and face-to-face; students' active involvement; effective communication between students as well as students and teachers; flexibility; regular and prompt feedback; personalization of the online environment); should involve different types of instructional Web-based technologies; incorporate various methods and techniques; focus on different types of tasks and activities including professional problem-based tasks; use different types and instruments of assessment (teacher assessment, computer marked assessment (e.g., testing vocabulary), peer assessment, self-assessment).

Keywords: prospective social workers, blended learning, English communication skills, webtechnologies.

\section{АНАСТАСІЯ МАЛОТА}

аспірантка

Тернопільський національний педагогічний університет імені Володимира Гнатюка вул. Максима Кривоноса, 2, м. Тернопіль

\section{ЗМІШАНЕ НАВЧАННЯ МАЙБУТНІХ СОЦІАЛЬНИХ ПРАЦІВНИКІВ ПРОФЕСІЙНО ОРІЕНТОВАНОГО СПІЛКУВАННЯ АНГЛІЙСЬКОЮ МОВОЮ}

\begin{abstract}
Обтрунтовано дочільність, проаналізовано та визначено особливості організації зміманого навчання майбутніх сочіальних працівників професійно орієнтованого спілкування англійською мовою. На основі опитування викладачів, а також працівників галузі визначено типові ситуачії міжкультурного професійного спілкування соціальних працівників. Встановлено, щцо ефективне професійно орієнтоване міжкультурне спілкування передбачає володіння студентами відповідними знаннями, лексичними, граматичними, фонетичними навичками, вміннями монологічного та діалогічного мовлення, а також лінгвосочіокультурними вміннями. Конкретизовано вимоги щзодо рівня володіння майбутніми соціальними працівниками вміннями професійно орієнтованого спілкування англійською мовою. 3 урахуванням специфіки англомовної підготовки майбутніх сочіальних прачівників, особливостей їх професійного міжкультурного спілкування зроблено висновок, щзо змімане навчання повинно бути спрямоване як на оволодіння змістом дисципліни, так $і$ на забезпечення ефективної співпрачі між студентами та викладачем, поєднувати навчання в групі та індивідуальне навчання; базуватися на особистісно орієнтованому та професійному підходах; відповідати обгрунтованим принципам (поєднання синхронного навчання з участю викладача, яке може бути як онлайн, так $i$ в аудиторії (приблизно 65-70\% часу), та онлайн-навчання, щуо може реалізовуватись як індивідуально, так $і$ в парах чи групах студентів (майже 30-35\%)); співпраця студентів в умовах офлайн та онлайннавчання; активна участь майбутніх фахівців у навчальному прочесі; ефективне спілкування між студентами та студентами і викладачем; гнучкість, щуо дозволяє вносити зміни в прочесі навчання; систематичний та оперативний зворотний зв'язок; персоналізація Інтернет-середовища); передбачати поєднання різних типів навчальних веб-технологій (системи управління навчанням (наприклад, Моодle), платформи для синхронних конференцій (BigBlueButton, Zoom тощо), ефективних циифрових інструментів (наприклад, Padlet)); включати різні методи та прийоми (веб-квести, дебати, дискусї, проєкти тощо); передбачати різні типи завдань і види діяльності, включаючи реальні проблемні завдання професійного характеру; використовувати різні види та інструменти оцінювання (оцінювання викладачем, автоматизоване комп'ютерне оцінювання (наприклад, тестування рівня володіння лексичною компетентністю студентів), взаємооиінювання, самооцінювання).
\end{abstract}

Ключові слова: майбутні сочуіальні працівники, змішане навчання, спілкування англійською мовою, веб-технології.

АНАСТАСИЯ МАЛОТА

аспирантка

Тернопольський национальный педагогический университет имени Владимира Гнатюка ул. Максима Кривоноса, 2, Тернополь 


\section{СУЧАСНІ ІНФОРМАЦІЙНО-КОМУНІКАЦІЙНІ ТЕХНОЛОГІЇ В ОСВІТІ \\ СМЕШАННОЕ ОБУЧЕНИЕ БУДУЩИХ СОЦИАЛЬНЫХ РАБОТНИКОВ ПРОФЕССИОНАЛЬНО-ОРИЕНТИРОВАННОМУ ОБЩЕНИЮ НА АНГЛИЙСКОМ ЯЗЫКЕ}

Обоснована целесообразность, проанализированы и обоснованы особенности организации смешанного обучения будущих сочиальных работников профессионально-ориентированному общению на английском языке. На основании опроса преподавателей, а также работников отрасли определень типичные ситуачии межкультурного общения сочиальных работников. Установлено, что эффективное профессиональное межкультурное общение предполагает овладение студентами соответствуюшими знаниями, лексическими, грамматическими, фонетическими навыками, умениями монологической и диалогической речи, а также лингвосочиокультурными умениями. Конкретизировань требования к уровню владения будущими сочиальными работниками умениями профессионально-ориентированного общения на английском языке. Сделан вывод, что смешанное обучение должно быть направлено на овладение содержанием и быть ориентированным на сотрудничество; основываться на личностно ориентированном и профессиональном подходах; соответствовать обоснованным приниипам (сочетание обучения с участием преподавателя, которое может проводиться как онлайн, так и в аудитории (приблизительно 65-70\% времени), и онлайн-обучения, которое может осуществляться индивидуально, а также в группах или парах (приблизительно 30-35\%); сотрудничество студентов в онлайн и офлайн режимах; активное участие студентов в учебном прочессе; эффективное общение между студентами, а также студентами и преподавателем; гибкость; систематическая обратная связь; персонализация интернет-среды); предполагать сочетание разных типов учебных веб-технологий; использовать различные методы и приемы; предполагать различные типь заданий и видов деятельности, включая реальные проблемы профессионального характера; использовать различные виды и инструменты оченивания (оченивание учителем, автоматизированное компьютерное оценивание (например, тестирование лексических навыков), взаимооченка, самооценка).

Ключевые слова: будущчие сочииальные работники, смешанное обучение, общение на английском языке, веб-технологии.

The importance of the English language in all the spheres of the modern world is hard to overestimate. As a result university graduates should be able to use the language effectively in different professional situations to attain the targets set. This fully applies to social workers who provide social protection to certain groups and categories of the population.

At the present stage, there are a number of studies on teaching English professional communication skills to students of different specialities: N. Dmitrenko (prospective teachers of Mathematics), O. Konotop (philology students), A. Onufriv (prospective marketers), S. Maslova (future winemakers) etc.

A significant amount of research on prospective social workers' training concerns teaching communication skills (L. Berezovska, R. Kurylovych, etc.). I. Bartosh studies teaching prospective social workers' German communication skills with the help of case method.

The use of ICT has encouraged the advancement of technology and Internet in education [14]. Blended learning, designed to provide various educational needs, plays an important role in the hightech modern society, which has experienced prolonged lockdown due to the coronavirus pandemic.

The analysis of scientific literature shows lack of research on the development of prospective social workers' English communication skills with the help of blended learning. There are no unified theoretical provisions that would determine the specifics of blended learning for communication in English; there is still a gap between students' special and language training; there is a need to develop a methodology of teaching English communication skills taking into account the requirements of the field.

The purpose of the article is to analyze and ground the peculiarities of blended learning for the development of prospective social workers' English communication skills.

Before proceeding to the study of blended learning, it is necessary to consider the specifics of future social workers' training. The first aspect that should be taken into account is the limited classroom time devoted to learning English, which requires the development of an effective methodology, focus on the most important content and involvement of efficient and motivating technologies. In our opinion, properly organized blended learning can provide students with appropriate technologies, present the material in a motivating way and save classroom time by ensuring balance between face-to-face and individual learning, synchronous and asynchronous activities, by suggesting problem-based tasks to be fulfilled online or offline. 
In order to provide the rationale for the development of prospective social workers' English communication skills through blended learning, it is necessary to analyze which skills should be considered. The results of the survey conducted among university teachers and social workers showed the necessity to focus on the following professional situations:

- informing about the services;

- consulting clients;

- establishing business relations with foreign colleagues;

- exchanging information with colleagues;

- delivering speeches at meetings, conferences.

- Within the above-mentioned situations social workers usually have to:

- present the information to the clients/audience;

- inform about the advantages and risks;

- visualize data/facts;

- persuade the audience/clients;

- ask for information;

- summarize information, data;

- prove the information;

- answer the questions in the area of expertise.

Communication includes both spoken production and spoken interaction. Thus, it requires knowledge, lexical, phonetic and grammar skills, skills of spoken production and spoken interaction, linguo-sociocultural skills, which provide the ability for multicultural communication [1, p. 425] (figure 1).

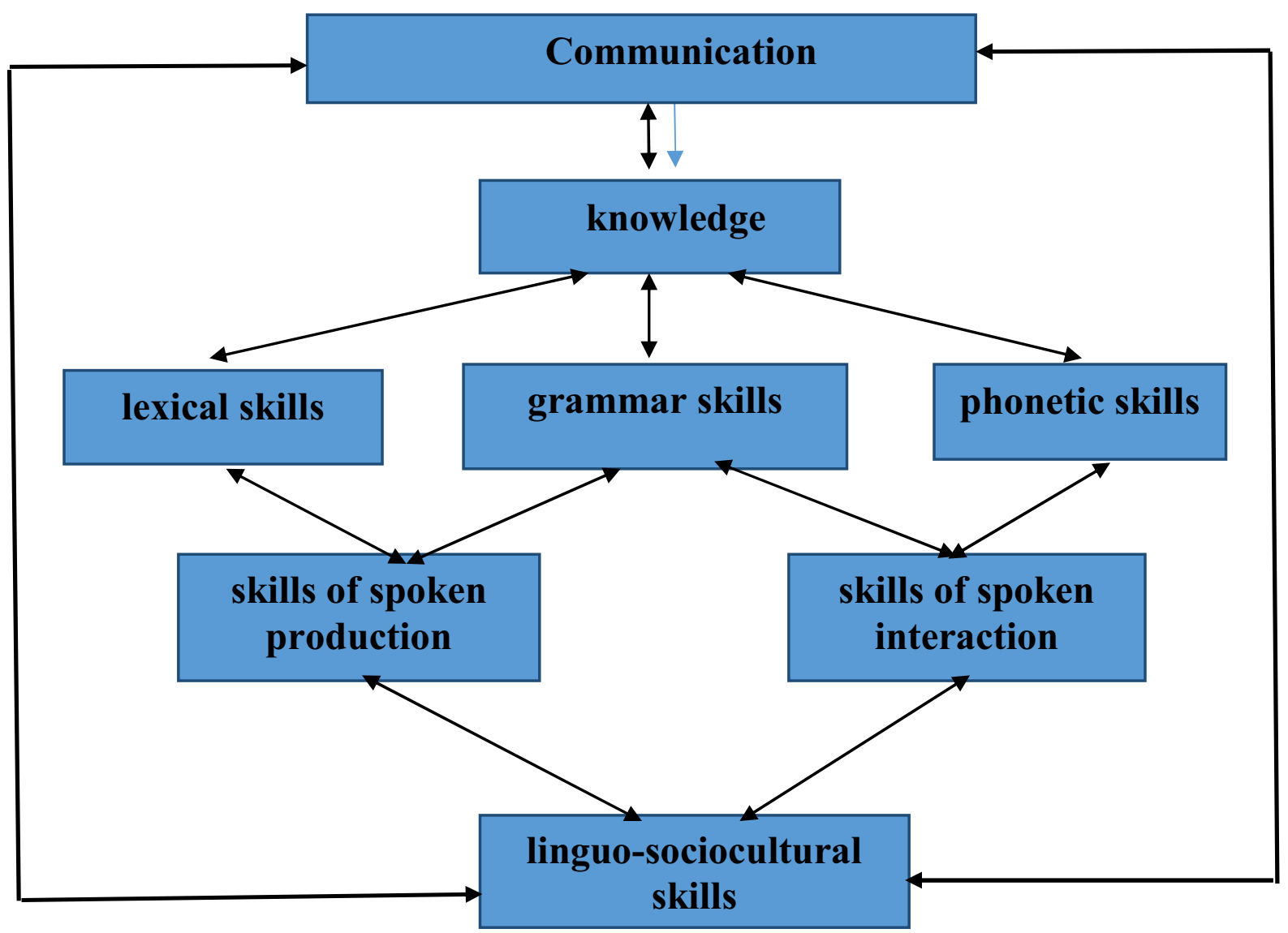

Figure 1. Communication skills of social workers.

The development of such skills, which are closely interconnected (figure 1), involves a lot of preliminary training on acquiring a range of vocabulary, structures and pronunciation features as well as intensive communication practice so that students can [2, p. 498-501]:

- speak spontaneously and quickly enough on the basis of the prepared text;

- briefly and accurately report on certain events; 
- correctly and accurately convey in detail professional information;

- convey a summary of large and complex texts;

- express their own opinion, giving appropriate explanations and arguments;

- clearly identify the problem, analyzing it;

- make prepared presentations on professional topics;

- use a wide range of means of communication;

- briefly comment on the views of others;

- use simple means of non-verbal communication;

- freely start a conversation, support and end it, taking into account the necessary register;

- initiate and maintain a conversation on familiar professional topics;

- confidently exchange detailed information within personal and professional interests;

- express objections, disagreements;

- encourage the partner / partners to express their own opinion;

- clarify the understanding of the statement made by the partner;

- participate in intercultural communication taking into account the linguo-sociocultural context.

The next step will be to analyze the peculiarities of blended learning aimed at developing prospective social workers' English communication skills.

Blended learning incorporates online learning into face-to-face teaching and learning methods $[18 ; 21]$. Blended learning includes deliberate and multiple combinations of face-to-face time (either virtually or in-person) and individual student online time, which can involve different forms of interactions [11]. As blended learning is not just a combination of online with face-to-face modes, the online part cannot be regarded as an addition to face-to-face teaching [10, p. 17].

Blended learning entails:

- effective integration of virtual and face-to-face methods [16] in a planned, pedagogically valuable manner [23];

- a trade-off (replacement) of face-to-face time with online activity (or vice versa) [23];

- integration of face-to-face verbal and online text-based exchanges in accordance with the appropriate learning tasks [27];

- combination of instructional modalities (onsite, self-paced learning, web-based), delivery media (internet, lectures, PowerPoint presentations, textbooks); instructional methods (face-to-face or technology-based sessions) and web-based technologies (wikis, chat rooms, blogs, textbooks, online courses) which are determined by the learning goals, course content, teacher experience and style, learner characteristics etc. [13].

Literature review [26] shows that blended learning is used: 1) to support face-to-face teaching [7]; 2) to provide pedagogical richness [17https://www.researchgate.net/profile/Charles-Graham3? $\mathrm{sg}_{0}$ 5B0\%5D=1OAnYNvEzmVcv74QrPp5HPlvn-

iCS4ISvj1GuRpjkc1YPHGFIyz2gOEOtZF7G7V71aWSfyQ.T-5OxZBD6LNFAp4cMeww14v1WJYXqb7PCTqxOvMAWyYGbuo5yJZP-DvZKHUktJlmYvbOsR3-

PTghpMEKVBxQ\& sg\%5B1\%5D=0glTTiNCRn2ULKr8WKJ3saNvEjZKzPSnPxqWKadEwo40qlx 1lalYw efshXq96prwiekAak.p4UhCuhNn95GY3Kf4f_s2ZhM177WruWHbCnuYgbDxWI6I8LUdout Hq3SeLGg4_hZWIVHtWkyfb6blor3YNCBvg]; 3) to develop collaboration [7; 15]; 4) to support communication [15] through social networking and interaction [17]; 5) to provide accessibility of learning materials [3] and ease of revision [17https://www.researchgate.net/profile/Charles-Graham3?_sg\%5B0\%5D=1OAnYNvEzmVcv74QrPp5HPlvn-

iCS4ISvj1GuRpjkc1YPHGFIyz2gOEOtZF7G7V71aWSfyQ.T-5OxZBD6LNFAp4cMeww14v1WJYXqb7PCTqxOvMAWyYGbuo5yJZP-DvZKHUktJlmYvbOsR3-

PTghpMEKVBxQ\&_sg\%5B1\%5D=0glTTiNCRn2ULKr8WKJ3saNvEjZKzPSnPxqWKadEwo40q1x 11alYw efshXq96prwiekAak.p4UhCuhNn95GY3Kf4f_s2ZhM177WruWHbCnuYgbDxWI6I8LUdout Hq3SeLGg4_hZWIVHtWkyfb6blor3YNCBvg]; 6) to reduce class time [20]; 7) to create interesting lessons $[25] ; 8$ ) to promote a motivating [20] and student-centered learning environment; 9) to provide flexibility in terms of time and location [26];10) to enhance students' independent learning skills [26]; $11)$ to support the existing teaching approaches and suggest individually tailored solutions [24];12) to support project-based learning and problem solving [15]. 
All in all, blended learning aimed at developing prospective social workers' English communication skills should meet the following requirements: develop collaboration, increase communication, provide accessibility of learning materials [3], motivate students, create a studentcentered learning environment, provide a balanced correlation of face-to-face (online and/or offline) and student online time (individual or in groups).

Researches determine four strategies of blended learning: 1) web-based delivery, which promotes students' independence, autonomy; 2) face-to-face processing, used to build a deeper understanding; 3) creation of products by students; 4) stimulating collaborative learning - groups meet to share and build upon [8].

The above-mentioned strategies are quite applicable in our investigation. The main emphasis is going to be made on collaborative learning, which is of utmost importance for building communication skills, and developing a student-centered environment, which will take into account the individual preferences of learners, their needs and experience.

According to M. Driscoll, blended learning may combine: 1) modes of Web-based technology (e.g., live virtual classroom, self-paced instruction, streaming video, audio, and text, collaborative learning) to reach an educational goal; 2) various pedagogical approaches (behaviorism, constructivism, cognitivism) to produce the expected learning outcome; 3) different forms of instructional technology (e.g., Web-based training, film) with face-to-face teacher-led training; 4) instructional technology with actual job tasks which creates the effect of learning and working [12, p. 54].

In our study blended learning is a combination of:

- different types of instructional Web-based technologies;

- various methods and techniques (web-quests, debates etc.) aimed at developing the abovementioned skills;

- web-based (individual or pair/group) learning and face-to-face group training, which can be conducted either online or in classrooms;

- different types of activities including problem-based task common for social workers.

There are different types of blended practices that are applied in higher education. Y. Kudrik, L. C. Lahn, and A. I. Morch distinguish between concept based blended learning and collaborationoriented blended learning. The former means the individual use of the online part which is actually a self-paced e-learning (concept training) and collaborative learning (simulations, seminars, group work) in the face-to-face part. The latter presupposes a computer-supported collaborative learning (e.g., virtual communities), and more individual oriented face-to-face part (e.g., traditional classroom instruction, PowerPoint presentation, mentoring). The authors made the conclusion about the necessity to enhance and direct self-paced learning or guide collaboration with peers in an online mode [19, p. 956].

Taking into account the job requirements, peculiarities of communication of social workers, the content and the context of learning as well as the necessity of strategic use of classroom time, which is limited, we have come to the conclusion that blended learning aimed at developing prospective social workers' English communication skills should combine the features of both types. For example, an online part may include collaborative online learning (e.g., completing a project) and self-paced elearning depending on the outcomes and the content. The face-to-face part should also be a combination of classroom instruction (e.g., grammar, vocabulary presentation when necessary) and collaborative learning through discussions, debates, problem solving activities etc. Online activities can be used either to get students acquainted with the topics and the materials to be used in class or to reinforce learning undertaken in the classroom [10, p. 17].

The construction of blended learning environment includes selection and development of interesting professional content, personalisation of the online environment, effective communication between peers and teachers, perceived ease of use of technology, course flexibility [10, p. 18], collaboration, prompt and regular feedback. Effective blended environment can provide behavioral (relating to students' actions, e.g., submission of work, contribution to class discussion), emotional (students' affective reactions to learning) and cognitive (students' psychological investment in their learning, e.g., use of communicative strategies, which goes beyond the requirements of the class) reactions [10, p. 19-20].

The analysis of the literature shows that there is the view according to which in blended course the proportion of content delivered online is from 30 to $79 \%$. To compare, a web-facilitated course presupposes that up to $29 \%$ of the content (assignments, syllabus etc.) is delivered online. In an online 


\section{СУЧАСНІ ІНФОРМАЦІЙНО-КОМУНІКАЦІЙНІ ТЕХНОЛОГІЇ В ОСВІТІ}

course most of the content (more than $80 \%$ ) is delivered online [6, p. 10]. Besides, two modes of blended learning are distinguished - adjunct, in which technology is used to enhance the face-to-face learning, and mixed, in which much learning is done online [22].

Since the development of communication skills requires a lot of oral practice and communication, in our case the lead mode will be face-to-face with the proportion of approximately $30-35 \%$ online and $70-65 \%$ face-to-face learning. However, depending on the situation and students needs some changes in the mode may be introduced to achieve the learning outcomes and meet students' expectations.

In blended learning the focus should be primarily on the learning, and then on the technologies that will provide the learning [9]. It is recommended that technology should be simple enough for the students to use [4] and easily accessible. Researches support the use of PowerPoint, interactive whiteboards, discussion boards, discussion groups, chat or conferencing, email, news groups, videoconferencing; phone calls, podcasts, social-networking sites, video clips, virtual worlds, weblogs and wikis etc. [5].

Blended learning for the development of prospective social workers' English communication skills should be organized within a learning platform, which provides both teachers and learners with different opportunities incorporating learner-centered tools. As most Ukrainian universities use Moodle, which contains tools with different functions (information transfer (book, file, URL etc.), interaction (blog, chat, forum, etc.), collaboration (wiki, forum, digital walls etc.), assessment (assignment, quiz etc.), management (calendar, announcements etc.)), it can be successfully used for online individual and collaborative learning. As it has already been mentioned, face-to-face mode can be done either in class or online. The latter may be organized through platforms like BigBlueButton, which can be well incorporated in Moodle and provide the opportunity to record the online sessions.

The main features of blended learning aimed to develop English communication skills of prospective social workers are summarized in Table 1.

Characteristic of blended learning aimed to develop English communication skills of

Table 1 prospective social workers

\begin{tabular}{|l|l|}
\hline \multicolumn{1}{|c|}{ Aspects } & \multicolumn{1}{|c|}{ Characteristics } \\
\hline Role of the teacher & $\begin{array}{l}\text { Creating learner-centered environment, motivating content; providing } \\
\text { online and face-to-face instructions; providing opportunity for } \\
\text { communication between students as well as teachers and students; } \\
\text { regular feedback. }\end{array}$ \\
\hline Role of the students & $\begin{array}{l}\text { Learner-centered approach (considering students' needs, interests, } \\
\text { experience) } \\
\text { Professional approach }\end{array}$ \\
\hline Approach & $\begin{array}{l}\text { combination of individual or pair/group online (approximately 30-35\%) } \\
\text { and online or offline face-to-face (about 65-70\%) learning; 2) online } \\
\text { and face-to-face collaboration; 3) students' active involvement; 4) } \\
\text { effective communication between students as well as students and the } \\
\text { teacher; 5) course flexibility; 6) regular and prompt feedback; 7) } \\
\text { personalization of the online environment. }\end{array}$ \\
\hline Principles & $\begin{array}{l}\text { various methods and techniques (web-quests, debates, discussions, } \\
\text { projects etc.) aimed at developing target skills. }\end{array}$ \\
\hline Methods and techniques \\
\hline Tasks and activities & $\begin{array}{l}\text { different types of tasks and activities including real problem-based tasks } \\
\text { for social workers. }\end{array}$ \\
\hline Materials presented online & $\begin{array}{l}\text { texts to read, audio, video, vocabulary exercises, grammar exercises, } \\
\text { professional situations and problems to be analyzed and solved, project } \\
\text { assignments. }\end{array}$ \\
\hline Technology & $\begin{array}{l}\text { learning management systems (e.g., Moodle), platforms for synchronous } \\
\text { conferencing (BigBlueButton, Zoom etc.), different digital tools (e.g., } \\
\text { Padlet). }\end{array}$ \\
\hline Assessment & $\begin{array}{l}\text { teacher assessment, computer marked assessment (e.g., testing } \\
\text { vocabulary skills), peer assessment, self-assessment. }\end{array}$ \\
\hline
\end{tabular}




\section{СУЧАСНІ ІНФОРМАЦІЙНО-КОМУНІКАЦІЙНІ ТЕХНОЛОГІЇ В ОСВІТІ}

All in all, having analyzed the peculiarities of prospective social workers' training and requirements to their English communication skills, we have concluded that blended learning should be a mixture of both concept based blended learning and collaboration-oriented blended learning with face-to-face mode as the lead one; must be based on learner-centered and professional approaches, correspond to the determined principles (combination of individual or pair/group online (approximately 30-35\%) and online or offline face-to-face (about 65-70\%) learning; students' collaboration both online and face-to-face; students' active involvement; effective communication between students as well as students and teachers; course flexibility; regular and prompt feedback; personalization of the online environment); should involve a combination of different types of instructional Web-based technologies (learning management systems (e.g., Moodle), platforms for synchronous conferencing (BigBlueButton, Zoom etc.), different digital tools (e.g., Padlet)); incorporate various methods and techniques (web-quests, debates, discussions, projects etc.); focus on different types of tasks and activities including professional problem-based tasks; use different types and instruments of assessment (teacher assessment, computer marked assessment (e.g., testing vocabulary skills), peer assessment, self-assessment).

\section{REFERENCES}

1. Metodyka navchannia inozemnykh mov i kultu: teoria i praktyka: pidruchnyk dlia stud. klasychnykh, pedagogichnykh i lingvistychnykh universytetiv [Methods of teaching of foreign languages and cultures: theory and practice: a textbook for university students]. O. B. Bigych, N. F. Borysko, G. E. Boreczka ta in.; za zagaln. red. S. Yu. Nikolayevoyi. Kyiv: Lenvit, 2013. 590 p.

2. Zadorozhna I. P. Teoretyko-metodychni zasady organizacii samostijnoi roboty majbutnikh uchyteliv z ovolodinnia anglomovnoiu komunikatyvnoiu kompetencieiu. Diss. dokt. ped. nauk [Theoretical and methodological foundations of self-study work organization on acquiring English language communicative competence. Dokt. ped. sci. diss.]. Kyiv, 2012. 770 p.

3. Aborisade P. A. Blended Learning in English for Academic Purposes Courses: A Nigerian Case Study. Blended Learning in English Language Teaching: Course Design and Implementation. B. Tomlinson, C. Whittaker (Eds.). London British Council, UK, 2013. P. 35-41.

4. Alberts P. P., Murray L. A. Stephenson J. E. Eight Educational Considerations for Hybrid Learning. Handbook of Research on Hybrid Learning Models: Advanced Tools, Technologies, and Applications. F. L. Wang, J. Fong, R. C. Kwan (Eds.). Information Sciences Reference: Hershey, PA, 2010. P. 185202.

5. Allan B. Blended Learning: Tools for Teaching and Training. London: Facet Publishing, 2007. 227 p.

6. Allen I. E., Seaman J. Sizing the Opportunity: The Quality and Extent of Online Education in the U.S., 2002-2003. Needham, MA: Sloan-C., 2003. 32 p.

7. Anderson P. What is Web 2.0? Ideas, Technologies and Implications for Education. JISC Technology and Standard Watch. $2007 . \quad$ Available at: https://citeseerx.ist.psu.edu/viewdoc/download?doi=10.1.1.108.9995\&rep=rep1\&type=pdf.

8. Barnum C, Paarmann W. Bringing Introduction to the Teacher: A Blended Learning Model. T.H.E Journal. 2002. No 30 (2). P. 56-64.

9. BlendKit Reader. L. Futch and B. Chen (Eds.). $3 \mathrm{~d}$ edition. Available at: https://blended.online.ucf.edu/blendkit-course-blendkit-reader-chapter-1/.

10. Bowyer J. Evaluating Blended Learning: Bringing the Elements Together Research Matters: A Cambridge Assessment Publication. 2017. Issue 23. P. 17-26.

11. Conrad J. R.-M., Donaldson A. Continuing to Engage the Online Learner: More Activities and Resources for Creative Instruction. Jossey-Bass, 2012. 176 p.

12. Driscoll M. Blended Learning: Let's Get Beyond the Hype. E-learning. 2002.3 (3). P. 54-56.

13. Dziuban C. D., Hartman J. L., Moskal P. D. Higher Education, Blended Learning and the Generations: Knowledge is power - no more. Elements of quality online education: engaging communities. J. Bourne, J. C. Moore (Eds.). Needham, MA: Sloan Center for Online. 2005. Available at: https://desarrollodocente.uc.cl/wp-content/uploads/2020/03/Knowledge_is_power_no_more.pdf.

14. Elliott D. Internet Technologies and Language Teacher Education. Handbook of Research on Web 2.0 and Second Language Learning. 2009. P. 432-450.

15. Ellis A. R., Steed, F. A., Applebee C. A. Teacher Conceptions of Blended Learning, Blended Teaching and Associations with Approaches to Design. Australian Journal of Educational Technology. 2006. 22 (3). P. 312-335.

16. Garrison D. R., Kanuka H. Blended Learning: Uncovering Its Transformative Potential in Higher Education. The Internet and Higher Education. 2004. 7 (2). P. 95-105. 


\section{СУЧАСНІ ІНФОРМАЦІЙНО-КОМУНІКАЦІЙНІ ТЕХНОЛОГІЇ В ОСВІТІ}

17. Graham C. R. Blended Learning Systems: Definition, Current Trends, and Future Directions. Handbook of blended learning: Global Perspectives, local designs. Bonk C. J., Graham C. R. (Eds.). San Francisco, CA: Pfeiffer Publishing, 2006. P. 3-21.

18. Holmes B., Gardner J. E-learning. Concepts and Practice. SAGE Publications Ltd, 2006. 200 p.

19. Kudrik Y., Lahn L. C., Mørch A. I. Technology-enhanced Workplace Learning: Blended Learning in Insurance Company. Proceedings of the 17th International Conference on Computers in Education. Hong Kong: Asia-Pacific Society for Computers in Education. 2009. Available at: https://citeseerx.ist.psu.edu/viewdoc/download?doi=10.1.1.548.6711\&rep=rep1\&type=pdf.

20. Leithner A. Review of Blended Learning: Using Technology in and Beyond the Language Classroom. Language Learning \& Technology. 2009. 13 (1). P. 33-39.

21. Littlejohn A., Pegler C. Preparing for Blended e-learning (Connecting with E-learning). Routledge, 2007. $298 \mathrm{p}$.

22. McDonald J. Blended Learning and Online Tutoring: A Good Practice Guide. Aldershot, UK: Gower, 2008. $203 \mathrm{p}$.

23. McGee P., Reis A. Blended Course Design: a Synthesis of Best Practices. Journal of Asynchronous Learning Networks. 2012. Vol.16. Issue 4. P. 7-22.

24. Mullamaa K. ICT in Language Learning - Benefits and Methodological Implications. International Education Studies. 2010. 3 (1). P. 38-44.

25. Pearcy A. G. Finding the Perfect Blend: A Comparative Study of Online, Face-to-face, and Blended Instruction. University of North Texas. Dissertations for PhD. Available at: https://digital.library.unt.edu/ark\%3A/67531/metadc11015/m2/1/high_res_d/dissertation.pdf.

26. Siew-Eng L., Muuk M. A. Blended Learning in Teaching Secondary Schools' English: A Preparation for Tertiary Science Education in Malaysia. Social and Behavioral Sciences. 2015. Vol. 167. P. 293-300.

27. Vaughan N., Garrison D. R. Creating Cognitive Presence in a Blended Faculty Development Community. Internet and Higher Education. 2005. 8 (1). P. 1-12. 